Journal of Educational Research in Developing Areas (JEREDA)

Vol. 2. Issue 2, Pp. 134-140, 2021

http://www.jeredajournal.com

E-mail: info@jeredajournal.com

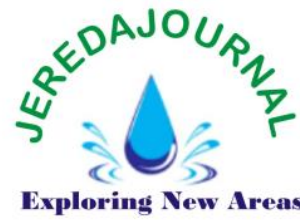

Mini Review DOI:https://doi.org/10.47434/JEREDA. eISSN:2735-9107

\title{
SCHOOL-BASED MANAGEMENT COMMITTEE'S CONTRIBUTIONS IN IMPROVING ACCESS TO BASIC EDUCATION IN KAURU LOCAL GOVERNMENT AREA OF KADUNA STATE, NIGERIA
}

\section{Tachio Joseph Biya}

Department of Educational Foundations, Kaduna State College of Education, GidanWaya, Nigeria

Email: josephtachio2016@gmail.com

(iDhttps://orcid.org/0000-0002-8358-0439

Received: $1^{\text {st }}$ July, 2021; Revised: $16^{\text {th }}$ July, 2021; Accepted: $21^{\text {st }}$ July, 2021

Introduction: The increasing number of out of school children in Nigeria is very disturbing. It is observed that many school age children are out of school and are seen in the streets roaming about aimlessly during school hours without access to education. This disturbing trend is a complete negation of one of Nigeria's philosophies of education which provides that education is a right of every Nigerian irrespective of gender, social status, religion, ethnic background and any peculiar individual challenges. This study examined School Based Management Committees (SBMCs) contribution in improving access to Basic Education in Kauru Local Government Area of Kaduna State.

Purpose: This review was to address the dearth in available literature for use by researchers, students, ministry of education and other related shareholders who will like to have access to literature to further strengthen and sustain school Based Management Committees contributions in improving access to Basic Education in Kauru Local Government Area of Kaduna state.

Findings: The paper reviewed the strategic contributions of school-based Management Committees in improving access to Basic Education in Kauru Local Government Area of Kaduna State. This is because children of school age still roam the streets without access to Basic Education in communities where schools do not have functional school Based Management Committees.

Recommendations: The paper recommended among others that; SBMC should be established and efforts should be made to ensure its effective functions in all Basic Education Institution in Kauru Local Government Area of Kaduna State, the government and community should reengineer advocacy for awareness and contributions of stakeholders in the provision of education.

Keywords:Communities' School-Based Management Committee, Contribution, Access, Basic Education

\section{Cite paper as:}

Crossref Biya, T. J.(2021). School-based management committee's contributions Cited-by in improving access to basic education in Kauru local government area of Kaduna state, Nigeria. Journal of Educational Research in Developing Areas, 2(2), 134-140. https://doi.org/10.47434/JEREDA.2.2.2021.134.

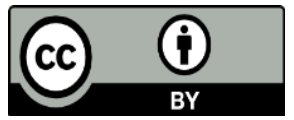

Copyright (c) 2021 The author(s) of this article retain(s) the copyright. 


\section{PUBLIC INTEREST STATEMENT}

Many school-aged children are seen roaming the streets in Kauru Local Government Area, Kaduna State, with no visible access to basic education. This is largely due to the interplay of related factors which have to do with school mapping challenges evidenced in poor location of schools, thereby relegating the UNESCO's benchmark of $2.5 \mathrm{kms}$ linear distance from home to school to the background. School mapping procedures are not often adhered to when locating schools, thereby leading to over concentration of schools where they are not necessarily needed while other areas suffer lack of such schools. Economic and cultural factors also contribute to denying school age children access to school. Out-of-school children can constitute security risks as they can easily be conscripted into criminal groups to worsen the already volatile security situation in Kaduna State. This review will be of interest to researchers, State Universal Basic Education Board (SUBEB), policy makers and other related stakeholders who will seek for literature with a view to discussing and addressing access to basic education related challenges.

\section{INTRODUCTION}

Education is an indispensable vehicle necessary for the promotion and sustenance of national growth development and social change. This is in addition to the crucial role it plays in the development of an individual into a sound and effective citizen. The case of Nigeria having 13.5 million children out of school is a clarion call to improve access to school (Oluwatosin, 2018). Education is a right of every Nigerian irrespective of gender, social status, religion, ethnic background and any peculiar individual challenges (Federal Ministry of Education, 2004). Thus, efforts should be taken to provide unrestricted access and equity to education for the total development of the child.

It is however disturbing to notice that many children in Kauru Local Government Area of Kaduna State are out of school without access to Basic Education. This indicates that the development of the children out of school into a morally sound, patriotic and effective citizens cannot be realized. This anomaly will give room to idle children ready to serve as easy pawns to perpetrate crime and cause chaos thereby further aggravating challenges related to poor access to Basic Education. Government efforts through the state Universal Basic Education Authority aimed at checkmating the problem of poor access to education have not yielded the needed results as children still roam the streets unabated. The use of threats and promise of sanctions by the government against parents who fail to send their children to school are yet to be translated into reality. This also indicate that Government alone cannot effectively address the challenges of poor access to education, hence the need to involve the community.

The lack of access to school calls for collaborative effort with development partners as well as the local communities to address access related challenges in Basic Education Institutions in Kauru Local Government Area. A relevant platform for addressing access related challenges is the School Based Management Committees (SBMCs). Kauru Local Government Authority in collaboration with Kaduna State Universal Basic Education Board (SUBEB) has made concerted efforts to stem the tide of poor access to school, but these efforts have not yielded the required results as many children still roam the streets without visible access to education. This necessitated the activation of School Based Management Committee (SBMC) to contribute their quota towards promoting access to Basic Education. It is against this background that this study examined the concept of School-Based Management Committee and its contributions in improving access to education, and creating awareness of SBCM in community. 


\section{CONCEPT OF SCHOOL-BASED MANAGEMENT COMMITTEE \\ School Based Management} Committee (SBMC) was established in all schools in Nigeria in 2006 with the approval of the National Council on Education (NCE). This was done to ensure inclusive participation in the school system. The SBMCs were expected to provide platforms for communities and schools to work together to enrich school governance and promote improved management by education authorities towards the achievement of better learning outcomes for children. The SBMC act as a bridge between schools and communities they serve. They contribute to school planning, advocate on behalf of the school and provide support to school activities (Universal Basic Education Commission, 2011).

The main objectives of SBMC include enhancing school governance for effective education services delivery, promote mechanism for accountability in the school system, encourage harmonious relationship between school, community, local Government Education Areas and Local Government Authorities, promote Community participation in school planning, monitoring and evaluation of school progress, promote and support schools to achieve set targets/benchmarks to yield better outcomes for children, create greater awareness and provide feedback to the larger community on issues that have to do with school governance, management regulations as well as planning, and promoting the participation of all groups within the community in decision making (FRN, 2006)

The SBMCs should be representative of the diverse groups in communities and generally made up of 12 to 19 people and it is a voluntary and non-political committee. The composition of the SBMCs includes the Head Teacher who serves as the secretary, representative of teachers, representative of students (Male and female) representatives of traditional rulers, former students representative, PTA representative (male and female) Youth representatives, artisan, Faith-
Based Organization (male and female) (Universal Basic Education Commission, 2011). The task of the aforementioned members of the SBMC is to ensure the translations of the objectives of the SBMC into reality with a view to promoting access to education.

\section{SCHOOL BASED MANAGEMENT COMMITTEE'S CONTRIBUTIONS IN IMPROVING ACCESS TO BASIC EDUCATION}

Community is a group structure, whether formally or informally organized, in which members play roles which are integrated around goals associated with the problems from collective occupation and utilization and habitual space (Zenter, 2004). Community service delivery is a process whereby the local people identify their needs, set their priorities, plan and implement them. It has to do with members' involvement in enrolling children in school, contributing money, labour and materials and attending PTA meetings at school. Members of the community participate in the execution of responsibilities or tasks delegated to them, as well as in decision making especially on matters relating to school governance, accountability and promotion of access to school. It is evident that good governance that recognizes and engages stakeholders in decision making process of education redirects parents' philosophy on the need to send their children to school (Human Development Initiatives, 2015).

Education institutions whether at local, state or Federal levels are established within designated geographical locations referred to as communities. Schools are located to address the needs of communities within which they are established. Community participation can therefore be seen as involving the communities in the management and improvement of the schools to enhanced teaching and learning activities. The basis for community participation revolves around deciding strategic locations for establishing schools to enhance access, intervention by the communities to mitigate the challenges posed by poor 
funding, enhancing collective ownership and control of education (Ede, 2000). Schools are often not fully financed by the government, and SBMC is an attempt to integrate the community into participation. Community participation through SBMC will definitely transform this arrangement and make schools become sensitive to community needs, a situation that can enhance access to Basic Education.

\section{SCHOOL BASED MANAGEMENT COMMITTEE AND ACCESS TO BASIC EDUCATION.}

The provision of equal access to qualitative basic educational opportunities for all citizens is very central in the establishment of the Universal Basic Education (UBE). This is because education plays a vital role in enhancing national development. Encouraging uninterrupted access to it at the primary and junior secondary school levels is a compelling necessity. The fact that education is a right of every Nigerian irrespective of gender, social status, religion and ethnic background further calls for the need to encourage access to it. It is however evident that several factors hamper access to it in Kauru Local Government Area of Kaduna State. These impeding factors include political, economic, cultural and lopsided enrolment related challenges.

Political influence is evidenced in the way community political leaders influence the location of schools arbitrarily without recourse to school mapping procedures (Udoh, Akpa \& Gang, 2010). This leads to over concentration of schools in some areas where they are not needed while other areas suffer lack, which denies access to education by children of these communities. It is necessary to note that school mapping is an essential exercise useful to rationally locate educational services of any type related to any level of education (Caillords, 2003). When schools are not located rationally, access to such schools can be hampered. Despite the Universal Basic Education (UBE) Act (2004) which advocated for free education, evidence abound to suggest that there are still some costs deterring some parents from sending their children to school and withdrawing those already in school from attending school thereby denying them access to school. Girls are often sent to work in the markets or hawk wares on the streets (Action Aid, 2011). This action denies children access to education. Several cultural factors also influence the value some parents attach to their children's education. Some parents believe that only boys inherit and carry on the family name, as such, they prefer boys to go to school (British Council, 2013). Other parents show hostility towards girl education as they tend to relate it to westernization which erodes good morals. This explains why enrolment of boys in most of the schools in Kauru Local Government Area appears to be remarkably higher than that of the girl child. Cultural practices which encourage early girl child marriage and placing the girl child in purdah deny them access to education.

In view of the foregoing, there is a very clear indication that efforts at sensitization of parents and the entire community by the government on the importance of education may not be adequate. Hence the need for a more robust effort to reposition the SBMC which serves as a bridge between schools and the communities they serve. The SBMC contributes to school planning, advocate on behalf of the school and provide support to school activities all aimed at improving access to school (Universal Basic Education Commission, 2011). The presence of representatives of Muslims, Christian, Youth, women organizations as well as PTA as members of the SBMC can further give impetus to aggressive advocacy, mobilization, and sensitization of parents and the entire community on the importance of education and the need to send their children to school. This sensitization can be done in Churches, Mosques, public gatherings and other related media. Effective sensitization will go a long way in dispelling erroneous notions and harmful cultural practices relating to the education and especially of the girl child 
thereby paving way for uninterrupted access to Basic Education in Kauru Local Government Area of Kaduna State.

\section{CREATING AWARENESS OF SBMC IN COMMUNITY}

Awareness in this case is concerned with the sensitization of the people through public enlightenment on the importance of education with a view to encourage them to send their children to school. The girl child is often discriminated against when it comes to access to education. Some parents believe that only boys inherit and carry on the family name, as such they prefer to send their sons to school (British Council, 2013). Other parents show hostility towards girls' education as they tend to relate it to Westernization which erodes good morals. Similarly, parents' fear of pregnancy outside marriage intensifies when girls reach puberty, sometimes inducing early marriage (Schaetzel, 2000). Marriage may be viewed in terms of protective mechanism shielding girls honour from potential shame of early unwanted pregnancy. There is the existence of socio-cultural prejudice that the school destroys established customs and respect due to parents and husbands (UNESCO, 2008). This is a very serious challenge that can have an adverse effect on access to education especially on the part of the girl child. It becomes necessary for SBMC to mobilize and sensitize the community on the need to contribute to the provision of education. Creating awareness on the benefits of sending children to school will go a long way in facilitating access to school.

Community participation in
advocating education through the
platform of SBMCs will no doubt pave
way for communities to positively
contribute to the development of Basic
Education. This is because SBMC drawn
from members of the community act as a
bridge between schools and the
communities they serve. They contribute
to school planning, advocate on behalf of
the schools. SBMCs help identify school
problems, participate in feasibility
studies, and engage in planning,

implement and evaluating of activities (Shaeffer, 2004). The aforementioned roles played by SBMC contribute in no small measure in creating school environments that are conducive, nonthreatening and necessary for improved access to school. It is important to realize that in some communities in Kauru Local Government Area, the boy child is the one often discriminated against in terms of access to education as some parents prefer to send their male children to the farm rather than send them to school. It is in view of this that the role of the SBMC in creating awareness can enhance access to school thereby solving the problem of out of school children in the area.

\section{CONCLUSION}

School Based Management Committees were established in all schools in Nigeria as part of governments' efforts to ensure inclusive participation in school. They were expected to provide platforms for communities and schools to work together to enrich school governance and promote improved management by education authorities towards the achievement of better learning outcomes for children. They act as a bridge between schools and the communities they serve on behalf of the school and provide support to school activities necessary for improved access to education. The major contributions of SBMCs towards improving access to Basic Education focus on creating awareness on the importance of education and enlightening members of the community on the need to send their children to school, encouraging community participation in school planning, monitoring and evaluation as this will give parents a high sense of belonging and $a$ feeling of being carried along in school management. It promotes school governance for effective community service delivery and enhancing democratization of school management thereby paving way for members of the community to take active part in decision making relating to school management and governance. 


\section{RECOMMENDATIONS}

Access to Basic Education is one of the major goals of education and enshrined in the national policy on education. Considering the fact that the provision of education is a huge national investment which government alone cannot effectively address, the involvement of the community through the platform School Based Management Committees (SBMCs) is a necessity. This is necessary to enhance unhindered access to education. In order to better position the SBMC to effectively contribute in improving access to Basic Education in Kauru Local Government Area of Kaduna State. It is recommended that;

1. The SBMC should ensure that major stakeholders are involved in educational mobilization, awareness and sensitization of members of the communities on the importance of education and the need to send their children to school.

2. There should be an aggressive campaign by the government at all levels to encourage community participation in school planning to ensure that the needs of the communities are appropriately captured and addressed.

3. Concerted efforts should be made by school administrators to ensure the promotion of good governance for effective service delivery of SBMC. This will facilitate accountability, transparency and trust that can facilitate access to education.

4. The school administrators should democratize school management by involving parents in decision making to promote SBMC goal achievements.

Conflict of Interest: The author declares no conflict of interest.

\section{Disclaimer}

I hereby declare that this paper is my autonomous work. All texts either quoted directly or paraphrased have been indicated by in-text citations. Full bibliographical details are given in the reference list. This work has not been submitted to any other examination authority.

\section{Notes on Author}

Joseph Tachio Biya is a graduate of College of Advanced Studies (CAS) Zaria, Kaduna state. He also holds a Bachelor of Arts (B.A.) in History from Ahmadu Bello University Zaria, as well as a Master of Arts (M.A.) in Educational Administration and Planning from the University of Jos Plateau State Nigeria. $\mathrm{He}$ is currently pursuing a Ph.D in Educational Administration and Planning in the University of Jos. He is a lecturer in the Department of Educational Foundations, school of Education, Kaduna State College of Education Gidan Waya. His research interests are in school mapping and access to Basic Education, School Planning and Access to Basic Education among others. He has attended local, national and international conferences and has written chapters in reputable textbooks and journals. He is married with children.

\section{REFERENCES}

Action Aid (2011). Transforming education for girls in Nigeria and Tanzania: A cross-country analysis of baseline research. Action Aid.

British Council. (2013). Gender equality in Nigeria report. British Council.

Caillords, F. (2003). Principalship and effective management of facilities. www.idpublicationsorg.

Ede, A.S. (2000). Educational administration and Management. Ichejum Publications.

Federal Ministry of Education (2006). Guide lines for the development of school based management committees (SBMCs). UBEC.

Federal Ministry of Education (2004) Compulsory and free universal basic education act 2004. NERDC.

Human Development Initiative. (2015). Improving governance and accountability in primary and junior secondary education in Nigeria. Paper presented at the workshop 
organized by HDI in collaboration with USAID, Abuja.

Oluwatosin, B. (2018). Number of out of school children in Nigeria rises to 13.5 million. www.thecable.ng.

Schaetzel, K. (2000). The Ideal project: A summary of results of formative evaluations. UNICEF.

Shaeffer, S. (2004). Collaborating for educational change.The roles of teachers, parents and the community in school improvement.UNESCO International Institute for Educational Planning.

Udoh, S. U., Akpan, G. O., \& Gang, K. (2010). Educational administration in Nigeria: Theory and practice. Education Press.

UNESCO (2008). The Dakar framework for action: Education for all: meeting our collective commitments. UNESCO.

Universal Basic Education Commission (2011). Revised guide lines for the development of school based management committees (SBMCS). UBEC.

Zenter, H. (2004). The state and the community. Sociology and Social research, 48, $414-437$. 